\title{
PRAEITIES SUPREKINIMAS URBANISTINĖSE ERDVĖSE
}

\author{
Rasa Čepaitienè \\ Lietuvos istorijos institutas, XX amžiaus istorijos skyrius, \\ Kražiu g. 5, LT-01108 Vilnius, Lietuva \\ El.paštas rasa.cepaitiene@if.vu.lt \\ Itteikta 20110315
}

\begin{abstract}
Santrauka. Straipsnyje ${ }^{1}$ siekiama panagrinėti keletą su praeities suprekinimu susijusių probleminių blokų postindustrinėse, postmoderniose vartotojiškose visuomenèse. Pirma, analizuojama, kaip šiuolaikinės globaliosios kultūros ekonomikos kontekste vyksta urbanistinių centrų ir ypač senųjų istorinių miestų bei jų ịvaizdžių komercializacijos procesas, kokias formas bei pavidalus jis igauna. Ir, antra, svarstoma, ką tai galètų reikšti, kitaip tariant, ką tai sako apie pačią mūsų visuomenès būklę ir požiūrị i praeitị. Neabejojama, kad adekvatus socioekonominių tendencijų, su kuriomis susiduria neoliberalizmo veikiami miestai, pažinimas yra itin aktualus pokolonijinių ir pokomunistinių šalių visuomenems, kurios, kaip kad Lietuva, vis dar ieško savojo tapatumo susidurdamos su ekonominès ir kultūrinès globalizacijos iššūkiais.
\end{abstract}

Reikšminiai žodžiai: istoriniai miestai, poindustrinė visuomenė, globalizacija, neoliberalizmas, suprekinimas, vartotojiškumas, paveldo industrija, kultūrinis turizmas.

\section{İvadas}

Esame ne tik miesto gyventojai, lankytojai, vartotojai, bet ir jo „skaitytojai“, konkrečiame miestovaizdyje kviečiami įžvelgti ir suprasti tam tikras ị ji „, „irašytas“ reikšmes. Viena iš tokio miesto „perskaitymo“ galimybių - pabandyti aptikti ir interpretuoti jame ideologijos paliktus pèdsakus. Eidami jais galime geriau suvokti ne tik tai, kokia pasaulèžiūrinè matrica buvo ar yra užkoduojama urbanistinèse erdvèse, bet ir koki poveikị jinai iki šiol daro miestų gyventojams ir jų svečiams.

Tad kaip viena ar kita ideologinè sistema veikia miestų formos bei sandaros kaitą? Totalitariniams bei autoritariniams režimams miestas labiausiai rūpi tik kaip įrankis ir galinga (aišku, ne vienintelè) priemoné, skirta masių indoktrinacijai bei pilietinei bendruomenei paversti politiniam elitui paklusnia minia (Abensour 1997). Vyraujant nacionalizmo ideologijai, urbanistinès erdvès, ypač valstybių sostinès, bandomos perinterpretuoti iš titulinès tautos perspektyvos, dèl to

\footnotetext{
1 Straipsnis parengtas vykdant LMT projektą „Atminties kultūrų formavimo strategijos Lietuvos urbanistinèse erdvèse“ (VAT-01/2010AM).
}

dažnai tampa gal ne visuomet akivaizdžių, tačiau realių ginčų ar net konfliktų arenomis, kur ịvairios politinès galios grupès, bendruomenès (etninès, konfesinès ir socialinès daugumos bei mažumos) ir atvykèliai (imigrantai ir ypač turistai) bando simboliškai ar realiai "savintis" ir savaip interpretuoti miestą (Čepaitienè 2008). Pavyzdžiui, iki šiandien tebesitęsiantys ginčai dèl Vilniaus „simbolinès priklausomybès“ yra šiuo atžvilgiu itin iškalbingi ir leidžiantys geriau atskleisti konkretaus miesto interpretacijų iš nacionalizmo ar nūnai madingo daugiakultū riškumo žiūros taško ypatumus (Čepaitienè 2009).

Tačiau, skirtingai nuo anksčiau minètų ideologijų, $\mathrm{XX}$ a. pabaigoje pasauliniu mastu pradejusi įsivyrauti nauja pasaulěžiūrinè ir vertybinè sistema - neoliberalizmas - linkusi savotiškai slapstytis ir vengia pernelyg afišuotis ar bent jau reiškiasi ne tokiomis rèksmingomis ir lengvai identifikuojamomis formomis. Ju apraiškas viešojoje erdvèje būdavo gana nesunku „demaskuoti “ dèl siūlomo monochromatiško tikrovès vaizdinio, dažniausiai ịsprausto ị miestovaizdị „,didžiojo ideologinio naratyvo" pavidalu, aiškiai apibrèžto individo 
vaidmens visuomenejje ir ryškesnių alternatyvų jam nebuvimo, o nūdienis postmodernusis kapitalizmas priešingai - siūlo nuolat besidauginančias begalinio, laisvo, nevaržomo ir neriboto pasirinkimo galimybes. Visgi, atidžiau pažvelgus, matyti, kad šie nuolat atnaujinami vartojimo troškimai ir pasirinkimai virsta savitiksliais ir beprasmiais. Tad miestai, užuot likę viešuju reikalu sprendimo erdvèmis, politinių idèju gimimo ir sklaidos, praeities didvyriu garbinimo, tautiniu bei pilietinių bendruomenių sutelkimo ir susirinkimo vietomis, šiandien virsta tik nuolat besisukančių „geismo mašinų“ fabrikais (Žukauskaitė 2004).

Neoliberalizmo ir konsumerizmo neakivaizdumas (vargu ar gatveje paklausti atsitiktiniai praeiviai sugebètų aiškiai apibūdinti, ką šie terminai iš viso reiškia, nors visi neabejotinai turès vartojimo ir pramogavimo patirties), pripažistant jų neịsisąmonintą, dèl to didesnę galią, kelia klausimą, kokią itaką naujosios socioekonominès tendencijos daro miestų pavidalui ir ịvaizdžiui? Juk globalinio kapitalizmo ịsigalèjimo etape miestai irgi virsta preke, ikainojama, reklamuojama ir pateikiama ant „tarptautinio prekystalio“. Atsižvelgiant i tai bei nūnai pasireiškiantị naują pseudomiestų fenomeną, kyla poreikis suprasti, kokios gali būti visų šių procesų pasekmès Europos bei Lietuvos miestams ir ypač jų urbanistiniam paveldui? Iš viso - kaip ir kodèl suprekinama praeitis, kad miestai virsta scena jau ne politinių, bet ekonominių veikèjų režisuojamam spektakliui? Kuo nuo totalitarinès minios, žinoma, išskyrus mobilizacijos laipsni, kokybiškai skirtųsi po „akropolius" besiblaškantys pirkèjų ir pramogautojų srautai?

Norint atsakyti i anksčiau iškeltus klausimus pirmiausia reikia panagrinèti kultūrinès globalizacijos ịtaką per pastaruosius keletą dešimtmečių vykusiai sparčiai miestų funkcijų bei ịvaizdžių kaitai ir paveldo industrijos daromą poveikị urbanistinems erdvems remarketizuoto kapitalizmo sąlygomis (Fulcher 2007: 76-88).

\section{Kultūrinė globalizacija, miestai ir paveldo industrija}

Nors istoriniai miestai visuomet buvo materialus tam tikrų ideologinių nuostatų atspindys, bet, specialistų manymu, tik XX a. II-oje puseje urbanistinè regeneracija tapo neatsiejama nuo sąmoningos kultūrinès politikos. Vakarų šalyse galima išskirti keletą miestų regeneracijos etapų, atspindinčių tam tikras tuo metu vykdytos kultūros politikos gaires (Bianchini 1999):

1) rekonstrukcijų laikotarpiu (pokaris - 7 dešimtmetis) buvo siekiama atkurti karo metu sugriautas ar apgadintas urbanistines struktūras ir kartu skatinti „aukštosios" bei tradicinès kultūros ịsisavinimą buvo statoma daug visuomeninių pastatų, teatrų, muziejų ir pan.;
2) socialinès integracijos laikotarpio (8 dešimtmečio pradžia -9 dešimtmečio vidurys) kultūros politikai didelę reikšmę turèjo po 1968 m. ịvykių susiklosčiusi padètis ir dèl to žymiai sustiprèjęs socialinis aktyvumas - feministinis, jaunimo, gejų, etninių mažumų ir pan. sąjūdžiai. Šios grupès kvestionavo tradicinę „aukštosios“ ir „žemosios" kultūros skirtị. Dèl to ir miestų plètros planuose buvo atsižvelgta ị ivvairių socialinių grupių bei „mažumų“ poreikius (pasirode eksperimentiniai teatrai, roko klubai, alternatyvioji žiniasklaida ir t. t.);

3) galiausiai nūdienis miestu vadybos laikotarpis (nuo 9 dešimtmečio vidurio iki šiol) pasižymi tuo, kad ekonominés plètros poreikiai globaliuoju mastu ima vyrauti sociopolitinių poreikių tenkinimo atžvilgiu. Gamybos būdų persiorientavimas pereinant ị poindustrinę (informacinę) visuomenès raidos stadiją akivaizdžiai daro ittaką ir miestų raidos strategijų pasirinkimui. Akcentuojamas ịvairialypių paslaugų sektorius, formuojamas naujas miesto ịvaizdis, paremtas kultūrinèmis bei kūrybinèmis industrijomis (ypač turizmu ir paveldu), skatinamos vidaus bei ypač užsienio investicijos ir t. t.

Dauguma socialinių analitikų, nagrinèjančių globalizacijos reiškinị ir jo poveikị miestams, sutaria, kad itin sudètinga trumpai ir aiškiai ji apibrežti bei ịvertinti. Viename labiausiai žinomų globalizacijos apibrèžimų ji tapatinama su „laiko ir erdvès kompresija“ (Harvey 1989). Išties, veikiant šiuolaikinèms telekomunikacijų ir informacijų technologijų naujovėms, „laikas“ nustoja būti vientisa nenutrūkstama praeities-dabarties-ateities grandine ir virsta nesibaigiančių ,dabarčių “ serija, savo ruožtu ,erdve““ dèl masinių komunikacijos bei modernių transporto priemonių naudojimo vis labiau „suspaudžiama“"(Dogshon 1999). Akivaizdu, kad masinis turizmas yra viena ryškiausių pasaulinès globalizacijos apraiškų (1 pav.).

Tačiau, jeigu kalbėsime apie kultūros paveldą, matysime, kad šiuo atveju pastaba apie „globalizacijos kompresinę jegą" lyg ir negaliotų, nes jis siejamas su konkrečiu istoriniu periodu atsiradusiais ir konkrečioje kultūrinejje bei geografinejje terpejje esančiais ar bent jau aiškiai identifikuojamais iš konkrečių vietų kilusiais dalykais. Net ir išplěšti iš savo natūralios aplinkos ir perkelti kitur šie artefaktai ar kultūrinès nuorodos geba išsaugoti sąsajas su savo kilmès vieta ir etnine bendruomene. Taigi, paveldas visuomet yra lokalus. Kartu, nepaisant bet kurio paveldo objekto, atrodytų, akivaizdaus „lokalumo“, galima kalbèti ir apie "globalụji paveldą", ypač turint omenyje UNESCO Pasaulio paveldo sarašo objektus arba vadinamuosius "globaliuosius paveldo produktus" (tokius, kaip ị tarptautinius vartojimo tinklus ịtrauktos nacionalinès virtuvès, muzikos, architektūros, dizaino stiliai ir pan.), seniai 


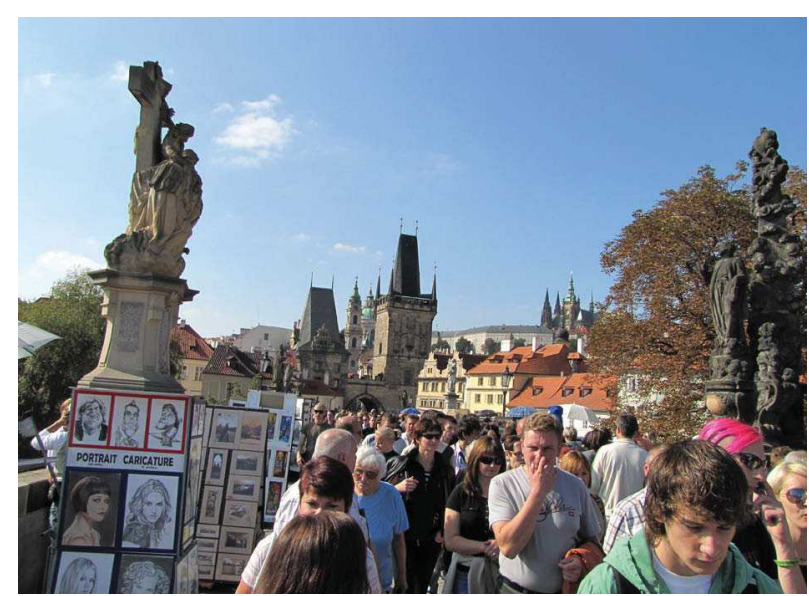

1 pav. Turistinis miestu užvaldymas pradeda kelti daug problemų vietiniams. Prahos Karolio tiltas vasarą. V. Kubiliaus nuotr.

Fig. 1. Occupancy of tourist cities starts causing many problems to local residents. Prague, Charles Bridge in summer. Photo by V. Kubilius

peržengusius juos sukūrusios kultūros ribas ir tampančius ryškiu kultūrinės globalizacijos stiprèjimo ženklu (Ashworth, Tunbridge 2003).

Šiandien bene ryškiausia globalizacijos ypatybe tampa vadinamoji kultūrinè homogenizacija, kai kurių kritikų vienareikšmiškai laikoma kultūrinio imperializmo apraiška (Sullivan 2007). Pagrindiniu jos varikliu laikomas vakarietiškos kilmès unifikuotos masinès vartotojiškos kultūros susiformavimas po Antrojo pasaulinio karo ir ligi šiol tebesitęsiantis dirbtinis jos reprodukavimas pasauliniu mastu. Globaliai fiksuojamas kultūrinių ženklų, simbolių bei prekių suvienodejjimas ir standartizacija prancūzų sociologui S. Latouche'ui leido šiuose procesuose įžvelgti radikalią pasaulinių kultūrų piktybinio „suvakarietinimo“ šmèklą, kuri iškelia Vakarų patirti, vertybes, gyvenimo stilių ir ignoruoja, nustelbia ar užgniaužia kitų kultūrų raiškos galimybes (Latouche 1996). Todèl kultūrų standartizacija ir niveliacija veda prie regioninès įvairovès nykimo (Benyon, Dunketley 2001). Galbūt dèl šios priežasties reikètų ieškoti ir nūnai stiprèjančio susidomejimo unikaliomis gamtinemis ar urbanizuotomis vietovèmis ir iš konkrečių kultūrų išaugusiomis paveldo vertybèmis priežasčių?

Kaip minètoji kultūrinè homogenizacija paveikia urbanistinio paveldo sritį? Nyderlandų paveldo ekonomikos profesorius G. Ashworthas yra pastebejęs, kad lokalumo ir globalumo ittampos įtraukia ir paveldotvarkos bei turizmo vadybininkus - „paveldas, kaip veikla, verslas ir investicija, yra iš esmès globalus, o ne lokalus. $<$...> Todèl tie, kas ji perka ir i jị investuoja, architektai ir dizaineriai, vietiniai projektuotojai ir politikai nori sumažinti riziką, imdamiesi projektų, kurie jau buvo sèkmingai łgyvendinti kitur“" (Ashworth 2009). Šių pa- veldo vadybos efektų pasekmės ypač ryškios istoriniuose, turistiniuose miestuose - paradoksas, vyksta unikalių paveldo vietų niveliacija, nes, užuot iggyvendinus kūrybiškus ir originalius sumanymus, jiems tvarkyti, pateikti ir interpretuoti pasirenkami jau kažkur kitur išbandyti ir laiko patikrinti modeliai.

Šiuolaikinès kultūros apraiškų - kultūrinès patirties suprekinimo, simuliavimo, fragmentavimo, tematizavimo ir t. t. pavyzdžių apstu ir vadinamojoje „paveldo industrijoje“, kurios susiformavimas Vakaru Europoje bei Šiaurès Amerikoje ir plètros pasauliniu mastu pradžia siejama su XX a. 8-9 dešimtmečiais ir laikoma tuo metu ịsigalejjusios masinès pramogų industrijos sudètine dalimi (Hewison 1987). Jos ištakose slypintis psichologinis „bègimo ị praeitį“ fenomenas kai kurių analitikų laikomas nesugebejjimo prisitaikyti ir adekvačiai atsiliepti ị dabarties keliamus iššūkius pasekme. Maitinimosi užeigų kompleksai, didžiuliai prekybos centrai, teminiai parkai, iš naujo suplanuoti ir perstatyti miestų centrai - visa tai sudaro bendrą eskapizmo ir konsumerizmo mišinit, kur susilieja kultūrine patirtis ir vartojimo praktika. Turizmas tampa vienu iš stipriausių nūdienos „paveldo bumo“ šaltinių, rodančių, kaip įvairiausi kultūriniai ir laisvalaikio užsiemimai susilieja su vartojimu, pramogavimu bei apsipirkinejiimu (2 pav.).

Paveldo industrija, kurios platesnis aptarimas itin svarbus norint adekvačiai suprasti istorinių, turistinių miestų suprekinimo procesą, kultūros specialistų, tarptautinio turizmo operatorių, vietinès valdžios ir miestų gyventojų vertinama anaiptol nevienareikšmiškai. Jos atsiradimas ir išpopuliarejimas bandytas aiškinti ịvairiai, ypač remiantis vadinamosiomis „visuomenès buržuazèjimo“ bei „bègimo ị praeitị“ teorijomis (Herbert 1995). Iš tiesų, muziejų ir paveldo vietovių lankymas šiandien laikomas kultūros paslaugų vartojimo (koncertų, teatrų ar meno galerijų

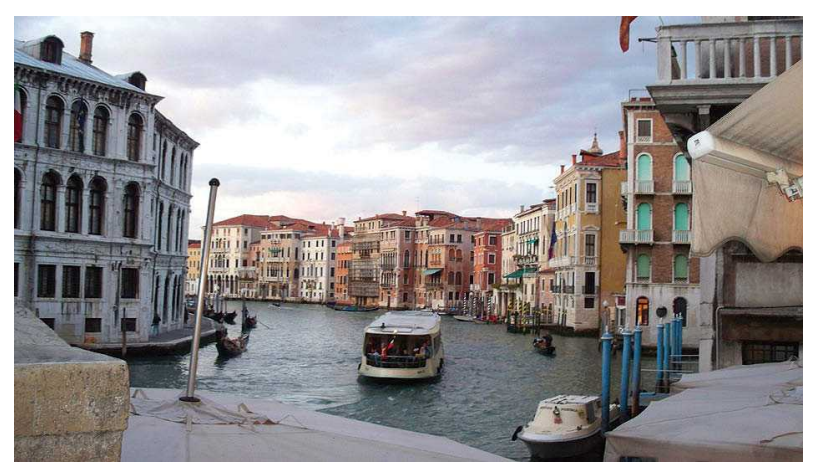

2 pav. Venecijos kanalais turistus vežiojančios gondolos ir kateriukai. Tikrieji venecijiečiai beveik nesinaudoja šia transporto priemone. R. Matuzevičiūtès nuotr.

Fig. 2. Gondolas and boats carrying tourists in Venice. Real Venetians use this means of transport (gondolas) very rarely. Photo by R. Matuzevičiūtè 
lankymo) sudetine dalimi; jis ankstesniais laikais tradiciškai buvo būdingas kone išimtinai socialinio elito atstovams, taigi sutapo su prabangos vartojimu. Tačiau $\mathrm{XX}$ a. II-oje pusejje, augant gyventojų perkamajai galiai ir išsivysčiusiose Vakarų šalyse formuojantis stipriam viduriniam sluoksniui, atsirado vis daugiau potencialiu kultūrinès produkcijos vartotojų iš platesnių socialiniu sričių. Tai lemmè kultūros apskritai ir paveldo konkrečiai demokratizaciją, tačiau kartu ir jos, virtusios masinio vartojimo dalimi, vulgarizacija. Kitas šio fenomeno aiškinimas, priešingai ekonominio pakilimo įtakos teorijai, paveldo industrijos bumą XX a. pab.-XXI a. pr. laiko „trumparegiška eskapistine nostalgija“, arba reakcija ị sąlyginị ekonomikos nuosmūkị XX a. 7-8 deš. tokiose šalyse kaip Didžioji Britanija, kur jis ryškiausiai pasireiške (Urry 1995). Panašu, kad bent jau Lietuvos atveju, nors, žinoma, kol kas trūksta išsamesnių šio klausimo tyrinèjimų (Vaitkuvienè 2006), galima kalbèti apie abi XXI a. pr. aiškiau pradejjusios reikštis paveldo industrijos paskatas - tiek vietos gyventojų perkamosios galios išaugimą ekonominio pakilimo 2005-2008 metais, tiek ir „bėgimo į praeitị" reiškinị.

Apibendrinant galima pasakyti, kad kultūros paveldo komercializacijos tendencijos turi tiek privalumų, tiek ir akivaizdžių trūkumų. Visų pirma, paveldo industrija, laikoma nauju kultūrinès produkcijos modeliu, be abejonès, suteikia vertę objektams bei vietovèms, kurie „kitaip neturètų jokių ekonominių perspektyvų“ (Kirshenblatt-Gimblett 1998). Tai funkcionalumą praradę ar prarandantys visuomeniniai, gyvenamieji ar industriniai pastatai, apleisti miestų kvartalai, vietovès ar artefaktai, pasenusios technologijos, apleistos šachtos, vargiai beegzistuojančios kultūros. Tad kartais tik pasinaudojus paveldo industrijos principais pavyksta prikelti jas iš „žiemos miego“ ir padaryti komerciškai rentabilias bei atraktyvias, kartu jas išsaugant (3 pav.). Vienas iš tokių pavyzdžių - 8-9 dešimtmečiais vykdyta Pensilvanijos (JAV) paveldo programa, nukreipta i masinès deindustrializacijos, kai net 65 proc. valstijos industrinių rajonų buvo apleisti ir nenaudojami, sukeltų socialinių problemų sprendimą. Taip buvo suteikta nauja paskirtis pastatams ir sukurta naujų darbo vietu bedarbiais tapusiems pramonèms darbuotojams, kurie galejo įsidarbinti gidais, pasakojančiais apie savo ankstesnį darbininko gyvenimą ir rodančiais jị ir taip iprasminančiais industrinị paveldą (KirshenblattGimblett 1998).

Tačiau pagrindiniai dabartinès paveldosaugos situacijos kritikai - britų specialistai D. Lowenthalis, K. Walshas, P. Fowleris, R. Hewisonas ir kt. - pabrežia, kad masinio turizmo pagimdyta paveldo industrija lankytojams palieka susipainiojimo laike, nesugebejjimo atskirti tiesos nuo melo, autentikos nuo kičo ir pan.

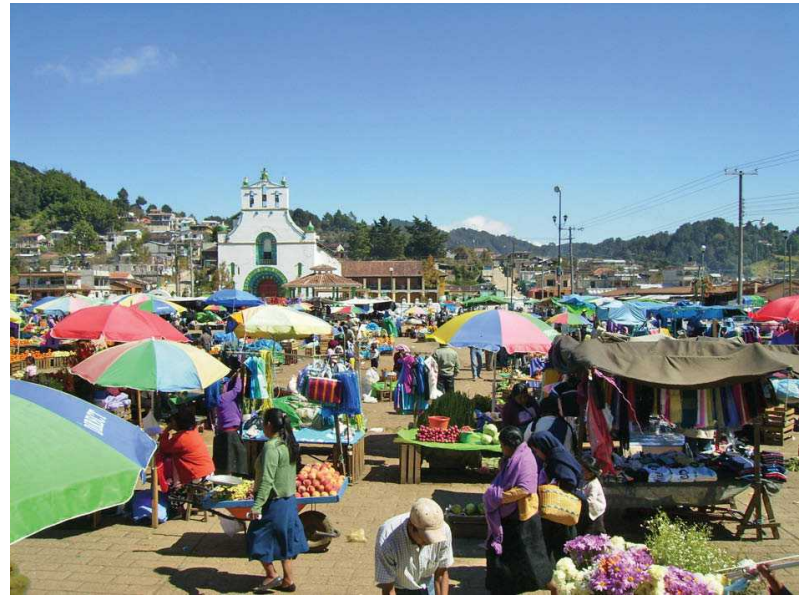

3 pav. Miesto turgus ir miestas kaip turgus. Gatvès prekyba vieno Meksikos miestelio centrinejje aikštèje. Ž. Mikailienès nuotr.

Fig. 3. A market of the city and a city as a market. Street market in the main square of one Mexican town. Photo by Ž. Mikailienè

ìspūdị. Apibrèžiant paveldą kone vien per jo vartotojo prizmę kinta tradiciškai ypač svarbi jo autentiškumo samprata bei išsaugojimo tikslingumas. Šiuo atveju ne pati istorinè tiesa, o vartotojas ịgalina produktą laikyti „autentišku“, nes skirtingiems vartotojams ,autentiški“ bus skirtingi dalykai (Ashworth 1994) ir šis, grynai ekonominis, požiūris labai kertasi su ịprastine paveldo apsaugos tikslų samprata. Tačiau tikroveje viskas sudètingiau, nes turizmo kontekste galima skirti „objektyvų" (šiuo atveju pabrèžiami kognityviniai tiesos apie tikrus, originalius dalykus pažinimo aspektai), „sukonstruotą“ (turisto su „kitokia“ kultūra siejamų ịsivaizdavimų, tikèjimų, nuostatų, stereotipinių įvaizdžių projekcija) ir „egzistencinį“ (šiuo atveju kelionès metu jau ieškoma nebe „kito“, o savęs paties) autentiškumą (McLeod 2006).

Kadangi globalizacija reiškia sparčią kaitą, tai veda prie greitejančios visuomenès transformacijos ir kaip pasekmé - jos destabilizacijos. Todèl išsaugota istorinè aplinka miestų gyventojams teikia psichologinio stabilumo, saugumo bei istorinio tęstinumo jausmą. Be to, itin svarbus tampa konkrečios fizinès vietos reikšmès suvokimo didejjimas deteritorizacijos kontekste, nes virtualios bendruomenès niekuomet negalès visiškai pakeisti realiųjų. Kita vertus, ekonominiu vystymu paremtos miestų paveldosaugos teikiama nauda aiškiausiai pastebima kuriant darbo vietas regeneruotose erdvèse, perteikiant senuosius amatus ir verslo igūdžius, plètojant vietinę technologijų, medžiagų ir darbuotojų pasiūlą. Taip pat senoji vietinè architektūra dažnai būna pranašesnè ergonomikos, šilumos ir kitų energijos rūšių panaudos atžvilgiu, lyginant su naują- 
ja, tarptautine, o senieji pastatai yra ne tik estetiškai aukštesnès kokybès, bet ir gali būti puikiai pritaikomi naujai funkcijai.

Tad urbanistinio paveldo apsauga ir miestų komercializacija nebūtinai turi būti vien antagonistinès. Kaip rodo daug pavyzdžių visame pasaulyje, tai gali tapti nepaprastai efektyviu miestu ar viso šalies ekonominio augimo akstinu. Kadangi skirtingi miestai turi skirtingus paveldo išteklius, kuriuos gali savitai, nemègdžiodami kitu, panaudoti ir taip tapti konkurencingi, tai, amerikiečių paveldo vadybos specialisto D. Rypkema'os nuomone, yra „nepralaimimas žaidimas“ (Rypkema 2005). Tad anaiptol ne visi urbanistinio paveldo specialistai vien skeptiškai ar pesimistiškai vertina miestų apsaugos ir pletros sankirtos perspektyvas.

Ši problema, kaip žinia, žymiai aktualesnè Lietuvai ir kitiems stambiems pokomunistinių šalių urbanistiniams dariniams, kuriuose aiškiai pasireiškia laisvosios rinkos daromas spaudimas pajung ti viešąją erdvę vien nežaboto pelno siekimo logikai (4 pav.). Gausūs ir dažni paveldosaugos reikalavimų pažeidimai Vilniaus senamiestyje, Kuršių nerijoje, Klaipedoje ir kitose istoriškai vertingose Lietuvos urbanistinese vietovèse atskleidžia, kad net įstatymais įtvirtintų apribojimų plètrai dažnai nepaisoma, ir tai vyksta ne tiek dèl teisiniu spragų, kiek dèl beatodairiško kapitalo diktato, kuris privačius komercijos, pelno interesus iškelia aukščiau viešųjų visuomenès poreikių. Kartu naikinamos ar žalojamos ne tik kultūros vertybès, gamtinè aplinka, bet nukenčia ir kitų piliečių interesai. Galiausiai iškreipiama ir pati urbanistinè raida. Pavyzdžiui, iki krizès per intensyvi ir net ekonomine logika jau nebepagrindžia-

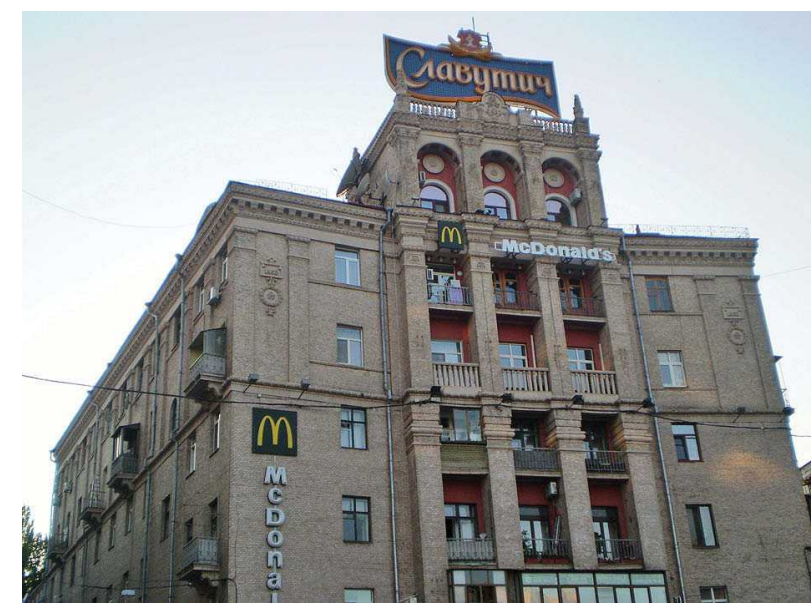

4 pav. Netikèti seno ir naujo sąskambiai. McDonalds iškabos ant stalininès architektūros pastato Kijeve, Maidane. R. Čepaitienès nuotr.

Fig. 4. A surprising consonance of the old and new. McDonald's signs on the Stalinist architecture building in Kiev, Maidan. Photo by R. Čepaitienè ma prekybos ir pramogų centrų plètra (tarkime, ar tokio dydžio ir gyventojų skaičiaus miestui kaip Šiauliai tikrai būtina turèti tiek stambaus masto prekybinių alejjų?) akivaizdžiai lèmè istorinių miestų centrų bei viešųjų erdvių tuštejimą ir estetinį degradavimą, kaip kad atsitiko Laisvès alejoje Kaune netoliese pastačius „Akropolic" (5 pav.).

Mūsų kasdienè patirtis rodo, kad gyvename ne tiek globaliame, kiek glokaliame pasaulyje, savotiškoje globalumo ir lokalumo sintezèje, persmelkiančioje ịvairias gyvenimo sritis. Glokalumo sąvoka yra japoniško žodžio dochakuka (pavertimas čionykščiu, vietiniu) adaptacija Vakaruose ir reiškia tuos sąlygų ir determinavimo būdus, kuriais vietose kuriamas, paskirstomas ir vartojamas globalus turinys (Robertson 2003). Kitaip tariant, globalizacini poveiki mes patiriame konkrečioje vietoje, taigi ir konkrečiame mieste. Šis poveikis ypač ryškus stambiuose urbanistiniuose dariniuose, kurie, pasak sociologų, nūnai jau savarankiškai išeina ị tarptautinę areną ir joje tarpusavyje konkuruoja, savarankiškai užimdami anksčiau joje dominavusių nacionalinių valstybių vietą (Castells).

Analogiškus miestų vaidmens kaitos procesus lemia ir eurointegracija. Masine migracija ir Europos Sąjungos skatinamas supranacionalumas (europietiškosios tapatybès kūrimo projektas) itin prisideda prie sparčios Europos miestų transformacijos ị heterogeniškas, daugiaetnes, daugiakultūres visuomenes (Graham 1998). Kaip žinia, remdamasi „fundamentaliụjų Bendrijos narių idejjų „apsaugos“ ir „sklaidos“ principais“, Europos Taryba nūnai yra užsimojusi skatinti Europos Sąjungos piliečių patirčių ir atmin-

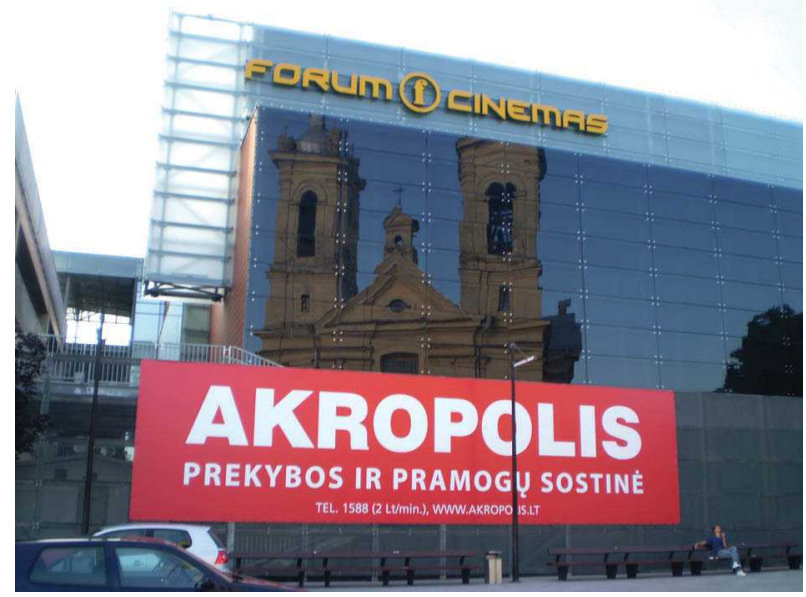

5 pav. Miestai mieste - tariamai viešos erdvès šiandien daro vis didesnę itaką miestiečių gyvensenai. Kauno "Akropolis". R. Čepaitienès nuotr.

Fig. 5. Cities in a city - pseudo-public spaces have an increasing influence on the way of life of city dwellers. "Acropolis" in Kaunas. Photo by R. Čepaitienè 
čių „europeizaciją“. Tačiau akivaizdu, kad Europos Sąjunga buvo ir tebera kuriama remiantis biurokratiniu, pragmatiniu ekonominiu, bet ne savimonès, kultūros pagrindu. Tad gali būti, kad šios pastangos bus bergždžios, juk ligi šiol nèra aišku, ką laikyti grynai „europietiškomis"vertybèmis, vizijomis, praktikomis, elgesio normomis ir kaip jas reiktų saugoti bei puoselèti (Wagner 2000). Tačiau minètasis G. J. Ashworthas būtent urbanistini paveldą laiko vienu iš potencialiausių „vieningos Europos“ konstrukto elementų, teigdamas, jog miestas, jo aplinka yra kasdieninè daugelio europiečių patirtis (Ashworth 1995: 74).

Tačiau „europietiškojo tapatumo" kūrimo strategija verčia nutraukti saitus su paveldosauga, tradiciškai orientuota ị nacionalinio paveldo dėmens išryškinimą. Ieškoma tų istorinių siužetų, ivvkkių, asmenybių, vietų ar objektų, kurie padètų išryškinti bendrąjj europinị matmeni - tam išties gali pasitarnauti atitinkamai aktualizuotas stambių daugiakultūrių miestų palikimas. Kita vertus, visame pasaulyje vykstantis miestų supanašejimas (ypač skatinamas international style architektūros ir miestų infrastruktūros bei komunikaciju analogiškų sprendimų) išryškina jų kosmopolitini matmení, paslepiantị vietinius savitumus. Tad kokia vieta šiuose procesuose tenka urbanistiniam paveldui, kaip matėme, susiejančiam globalųjị ir lokalųjt lygmenis, dažnai apeinant kone išimtinai „vidaus reikmèms“ paliekamą nacionalinį?

\section{Miestų paveldo suprekinimo ypatumai}

Iš pirmo žvilgsnio būtu galima teigti, kad pagrindinè urbanistinio paveldo komercinès panaudos forma yra paveldo turizmas (daugiausia atvažiuojamasis, nors, žinoma, vietinio irgi nereikètų pamiršti). Sudarant turistinius kelionių maršrutus didelę reikšmę turi ne tik istoriškai susiklostę lankytinų miestų įvaizdžiai, kurie dažnai, nors nebūtinai visuomet, būna stereotipiniai, bet ir tuo metu vyraujančios tarptautinio turizmo konjunktūros. Turima omeny, kad vieni ar kiti regionai, šalys ar miestai dèl vienokių ar kitokių priežasčių gali staiga pasidaryti patrauklūs ir madingi - todèl gausiai lankomi arba nelauktai šią trauką prarasti. Ir taip gali atsitikti nepaisant realių ar potencialių juose esančių paveldo išteklių vertès bei vadybos sèkmių ar nesèkmių.

Ankstyviausia, tačiau ir nūnai reikšmès nepraradusia turizmo forma galima laikyti piligrimystę $(6,7$ pav.). Nors iš esmès piligrimų ir turistų tikslai skiriasi (pvz., išgijimo ar Dievo malonès išprašymo intencija pirmuoju atveju ir tiesiog nauji ịspūdžiai, pramogos, kitokia, egzotiška patirtis antruoju), tačiau abiem atvejais sakralių bei istorinių vietų lankytojai susiduria su autentiškais arba tokiais laikomais praeities reliktais, kurie yra tik toje konkrečioje vietoje.

Šiandien kai kurie turizmo tyrinètojai išskiria 5 turizmo vystymosi fazes, kurios, kaip matysime toliau, turèjo didžiulès reikšmès praeities suvokimo kaitai. Pasak A. R. Cuthberto, galima skirti:

1) klasikinį, autentiškumo paieška užsièmusị turizmą (iki XX a. vid.);

2) su masinio turizmo plètra vèliau atsiradusi „surežisuotą autentiškumą", kai buvo rekonstruojami miestai, įvykiai ar artefaktai;

3) vadinamąji „postturizmą", kuriam jau neberūpi autentiškumas", juo tiesiog žaidžiama;

4) „teminị turizmą“, t. y. teminių parkų ir prekybos alejų, kurie dažnai tarpusavyje susilieja, pasaulį, kuriame autentiškumo klausimas jau nè nebekeliamas; 5) „virtualųji turizmą“, tarpininkaujamą naujausių kompiuterinių technologijų, kai autentiškumas (virtualioji patirtis) jau igauna visiškai naują prasmę (Cuthbert 2006: 114).

Aštuntajame XX a. dešimtmetyje išsivysčiusiose šalyse formavosi „vartojimo dèl vartojimo“ filosofija (Urry 1995). Ekonomikos sociologijoje buvo konstatuota, kad gamintojų rinka tapo vartotojų rinka. Tuo pat metu dideli pokyčiai vyko turizmo bei aptarnavimo srityje - buvo pereinama nuo konvejerinio pobūdžio turizmo, kai keliautojų poreikius tenkino masinè konvejerinio pobūdžio pasiūla (kuriai buvo būdingas sąlyginis primityvumas ir vienarūšiškumas, beasmenis „konvejerinis“ paslaugu gamybos pobūdis) prie diferencijuoto turistinès pasiūlos modelio, kuriame ryškejja specializacija ir diversifikacija, reiškianti ịsigilinimą $\mathfrak{i}$ klientų poreikius bei motyvus ir turistinių produktų pasiūlos įvairovę. O paskutiniame dvidešimto amžiaus dešimtmetyje pradèjo ryšketti turizmo individualizacijos kryptis, veikiama vis ryškesnių ekonomikos humanizacijos, socializacijos ir ekologizmo tendencijų, kai visuomenès dèmesio centre vèl atsirado asmenybè su savo poreikių spektru. Taigi vietoj „vartojimo dèl vartojimo“ isigalejo „vartojimo, sukeliančio potyrius“ filosofija, kai prekè arba paslauga perkama dèl to, kad jos vartojimas leidžia patirti naujus ịspūdžius ar padeda igyti naują individualų patyrimą (Pine, Gilmore 1999). Taigi pagrindine lankomo objekto verte tampa jo potencialas potyriams reprodukuoti.

Masinis turizmas, tačiau ne jis vienas (prie to itin prisideda ir žiniasklaida, reklama bei viešieji ryšiai), yra ryškus pavyzdys, kaip gyvenime ėmé dominuoti tariami ívykiai ir inscenizuoti potyriai. Šiuolaikiniai turistai tampa pasyviais stebetojais, savotiškai izoliuotais nuo lankomos šalies. Juos netgi galima laikyti savotiškomis „turizmo industrijos aukomis“, tarsi laikomomis turistiniuose „getuose“, griežtai kontroliuojant jų potyrius. 


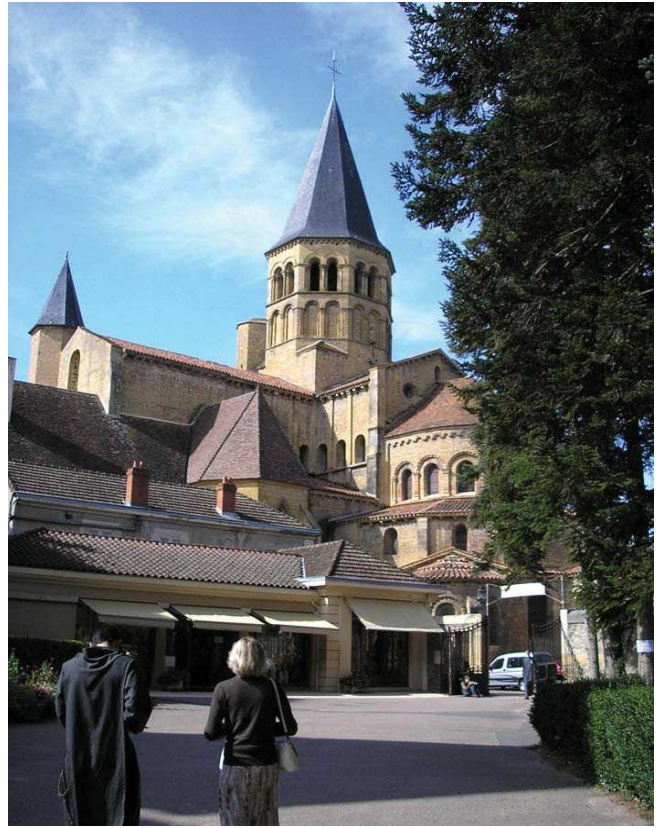

6 pav. Garsieji piligrimystès centrai - turistiniu maršrutu pirmtakai. Pare le Monialis, Prancūzija. R. Čepaitienès nuotr.

Fig. 6. Famous centres of pilgrimage - predecessors of the tourist destinations. Paray le Monial, France. Photo by R. Čepaitienè

Kai kas supranta turistus kaip šiuolaikinius piligrimus, bėgančius nuo paviršutiniškos, nestabilios ir praradusios savo autentiškumą moderniosios visuomenès ir ieškančius įsivaizduojamo autentiškumo (Jokinen, Veijola 2008). Kiti juos mato kaip žmones, kurie keliaudami „pasikrauna“ papildomų jègų, vèliau prireiksiančių kasdieniniame gyvenime. O dar kiti šiuolaikinius turistus suvokia kaip postturistus, kurie nè nebesitiki išgyventi kažką tikro (Urry 1990: 11). Taigi autentiškumo ir suprekinimo klausimai turizmo kontekste iki šiol lieka vieni labiausiai svarstomų. Tad galima sakyti, kad paveldo turizmas - tai autentiškumo, skirtingu kultūrų ir civilizacijos „nesugadintų“ vietovių paieškos (Craik 1997: 114). Tačiau net tais atvejais, kai turistui visiškai nerūpi paveldas, jis vis tik prisideda prie paveldo industrijos, pavyzdžiui, apsigyvendamas istoriniame pastate įrengtame viešbutyje, kad ir kitais tikslais lankydamasis istorinèse paveldo vietose, pirkdamas vietinius produktus bei suvenyrus ir pan.

Svarbu turèti omenyje, kad masinis turizmas, dažnai kildinamas iš „nostalgijos“ idealizuojamai ir miglotai bei stereotipiškai apibrèžiamai „praeičiai“ bei "senoviškumui“, buvo specialistų nemažai kritikuotas dèl polinkio suprekinti ir standartizuoti kultūrinę patirtị ir laisvalaikio leidimo būdus (tai vadinamoji „makdisnejizacija“, kurios ypatumus yra aptarę ame-

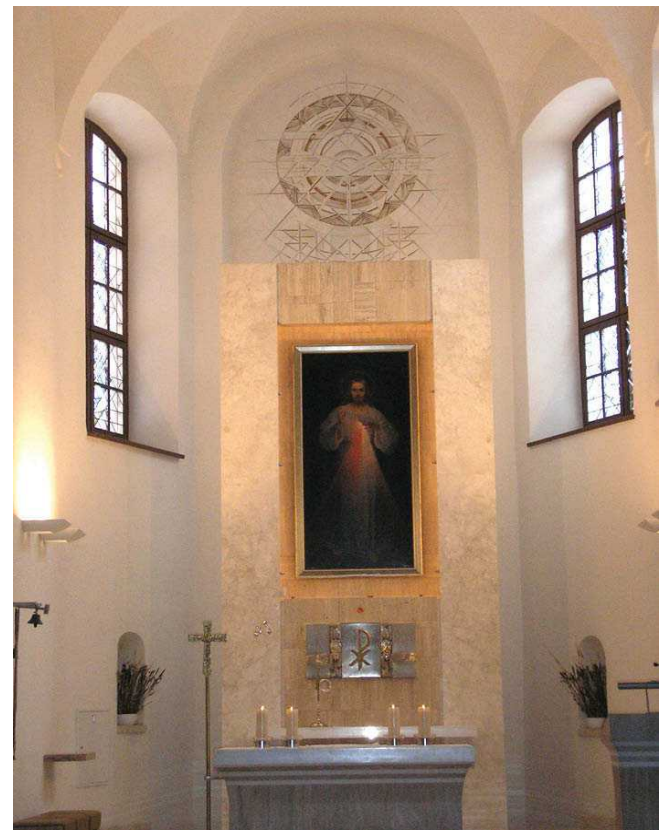

7 pav. Vilnius - gailestingumo sostinè. Kataliku garbinamas Gailestingojo Jèzaus paveikslas - jau ir turistų pamègtas objektas. R. Čepaitienès nuotr.

Fig. 7. Vilnius - the capital of divine grace. The painting of the Merciful Jesus Christ, worshiped by Catholics, is a touristic object on its own. Photo by R. Čepaitienè

rikiečių sociologai G. Ritzeris ir A. Liska (2002)) ir kartu suprimityvinti masiniu virtusị kultūros vertybių vartojimą. I minètąją sąvoką telpa keletas tam tikrų bruožų, kurie būdingi tiek Disney’aus parkams (8 pav.) ir McDonald's restoranų tinklui, tiek ir turizmo industrijai. „Disney’aus pasaulio“ ženklus ir McDonald's restoranų siūlomą produkciją galima lengvai atpažinti bet kuriame pasaulio mieste. Abi kompanijos deda visas pastangas, kad lankytojas nepatirtų jokių netikètumų. Tas pats matyti ir turizmo industrijoje: praktiškai šalia visų lankomų vietovių ar net jų pačių teritorijoje (pvz., Vilniaus senamiesčio atveju) kuriasi specialiai turistams pritaikytos standartizuotos maitinimo įstaigos, dažniausiai siūlančios standartiškus, tokius pat visame pasaulyje meniu. Be to, ir patys viešbučiai yra labai standartizuoti, kad tik turistas nepatirtų jokių nepageidautinų siurprizų ir galètų jaustis „kaip namuose“. „Makdisnejizacija“, jeigu akcentuosime turistinių paslaugų griežtą standartizaciją, lankytojų kontrolę ir jų gaunamų patirčių prognozuojamumą, kaip ir tematizavimas, kurį urbanistikos analitikai labiau linkę sieti su šiuolaikinio „parduodamo miesto“ estetinio dizaino raiška (Cuthbert 2006: 194-200) - bene akivaizdžiausi miestų turistinio suprekinimo demenys.

Sekant „makdisnejizacijos“ modeliu istorinių, turistinių miestų centrai vis labiau panašèja ị teminius 
parkus. Vienas iš urbanistinio paveldo praktinio panaudojimo turizmui pavyzdžių būtų senuosiuose pastatuose įrengiami dažnai standartizuoti, visiškai prie autentiškos aplinkos netinkantys viešbučiai, restoranai ar parduotuvès (pvz., Šekspyro viešbutis Vilniuje).

Paprastai bilietui į Disney’aus parką lankytojas išleidžia mažiau nei lankymosi parke metu pirkdamas ivairius Disney'aus produktus (pradedant maistu ir baigiant suvenyrais), kurie ten kainuoja žymiai brangiau nei už parko teritorijos ribų. Analogiškus dalykus galime pastebèti ir turistų lankomuose senamiesčiuose - čia paslaugos ir produktai kainuoja žymiai brangiau nei kitur mieste. Šie šalutiniai miestų atverimo užsienio turizmui efektai kartais net prisideda prie vietinių gyventojų išstūmimo iš istorinių centrų. Ir nors Vilniuje šis senamiesčio, ypač Pilies gatvès, turistinis „užvaldymas“ kol kas lieka sezoninis, tačiau galbūt plèsis. Kitos su tuo susijusios problemos - turistų spūstys, didèjantis eismas ir triukšmas, nuo kurio labiausiai kenčia žymiausi turistinès traukos centrai - Venecija, Florencija, Paryžius, Barselona, Briuge, Krokuva, Praha ir t. t.

Be to, lankytojams siūlomi specialūs produktai, sukurti dažnai naudojantis lokaliomis paveldo vertybèmis: paveldo vietas pristatantys filmai, knygos, ịvairūs suvenyrai, maisto produktai, gèrimai, drabužiai ir pan., kurie vilioja turistus įsigyti „autentišką prekę iš autentiškos vietos“. Deja, jie pateikia tarptautiniu mastu lengvai atpažistamus simbolius ar asociacijas, kartais mažai ką bendro turinčius su konkrečių miestų tikrąja praeitimi (pvz., aiškiai ị turistus orientuotos gintarinių dirbinių ir lino parduotuvès Vilniaus senamiestyje (9 pav.) ar Kinijoje pagaminti „tradiciniai“ Briugès

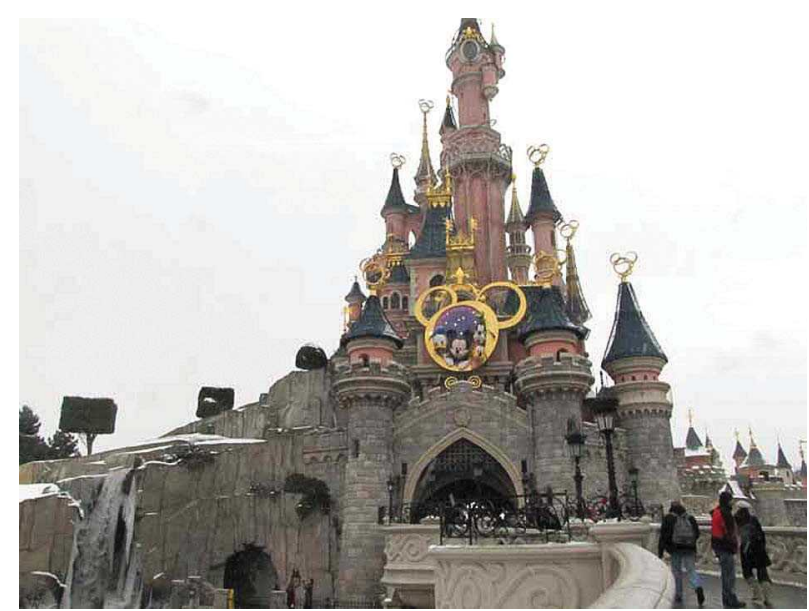

8 pav. Paryžiaus Disneilendas. „Makdisnejizacija“ - ryškus globalizuotų miestų ženklas. V. Kubiliaus nuotr.

Fig. 8. Disneyland in Paris. "Mcdisneysation" - the distinct sign of globalised cities. Photo by V. Kubilius nėriniai) - taip iškraipoma ar subanalinama ne tik istorinè tiesa, bet ir estetinès vertybès.

Panašiai suprimityvinama ir turistams perteikiama miestų istorija. Ir nors gidai gebètų pateikti lankytojams ịvairesnị ir reljefiškesnị praeities vaizdą, tačiau dažniausiai jie apsiriboja lengvai suvokiamu pasakojimu, neverčiančiu turistų narplioti painių miesto praeities vingiu (Muzyn 2009). Visa tai reiškia, kad istorinių miestu centruose, lygiai kaip ir teminiuose parkuose, visa turistinių paslaugų industrija yra kruopščiai planuojama ir kontroliuojama.

Kitas „makdisneizacijos“ aspektas, pasireiškiantis turizmo industrijoje, yra potyrių ir patirčių (experience) paieškos. Nors svetimo miesto lankymas, anot turkų paveldo apsaugos ir vadybos specialistès Aylin Orbaşli, jau pats savaime tampa nauja unikalia patirtimi, turizmo ir pramogų sektoriuje vyrauja supratimas, kad visai kaip Disney'aus teminiame parke, kuriame viskas iš anksto numatyta ir surežisuota, turisto patirtis irgi turi būti dirbtinai sukonstruota, kontroliuojama ir apgalvotai pateikiama (Orbaşli 2002: 79). Istoriniame mieste paprastai stengiamasi dirbtinai prikurti pačių įvairiausių laisvalaikio praleidimo būdų, teikiančių kuo įvairesnių patirčių, pvz.: amatų demonstravimas, nacionalinès virtuvés ar vynų degustacijos, apsipirkinejjimas „nacionalinių produktų“ ir suvenyrų krautuvèlèse, pasivažinèjimas specialiomis transporto priemonèmis, apsilankymas įvairiuose renginiuose ir t. t. Taigi istoriniame mieste patirtys dažniausiai būna neatsiejamos nuo vienaip ar kitaip išnaudojamų paveldo produktų.

G. J. Ashworth'as ir J. E. Tunbridge'as išskiria keletą bruožų, atskleidžiančių, kodèl būtent istoriniai mies-

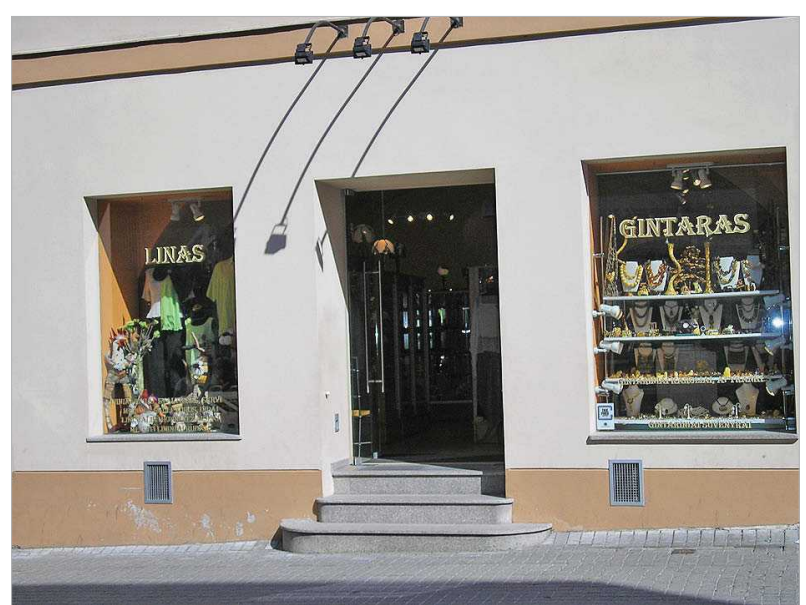

9 pav. "Lokalūs produktai“ ir globalioji turistinè prekyba neatsiejami? Vilniaus senamiesčio vaizdas. R. Čepaitienès nuotr.

Fig. 9. "Local products" and global tourist commerce become inseparable. The view on the Old Town of Vilnius. Photo by R. Čepaitienè 
tų centrai, turintys gausų urbanistinị palikimą, tampa patraukliausia vieta mieste rastis ịvairioms komercinèms veikloms. Pirmiausia senoji miesto dalis yra tarsi apdovanota ypač magiška istorine atmosfera, kuri neišvengiamai „apgaubia“ ir visas įstaigas, esančias senamiestyje. Antroji palanki istorinio miesto savybè yra didelis besilankančių turistų, potencialių klientu skaičius. Trečiasis senamiesčio kaip palankios komercinei veiklai vystyti vietos bruožas yra daug panašią ar kitokią veiklą vystančiu îstaigų. Juk šių laikų visuomenëje komercinè veikla dažnai yra vystoma "tinklo“ pavidalu, vienos įstaigos yra priklausomos nuo kitu, čia pat šalia kuriasi tiekèjai ir partneriai (Ashworth, Tunbridge 2000: 107-108).

Prie šių istorinio miesto komercinès panaudos privalumų dar galima būtų priskirti ir „gražaus vaizdo pro langą" savybę. Šis privalumas ypač svarbus viešbučiams, kuriems galèjimas disponuoti įspūdingo istorinio miestovaizdžio teikiamu estetiniu efektu gali lemti didesni lanky tojų skaičiu, taigi ir didesnị pelną. Tačiau miestas, tiksliau jo vizualinè plotmé, suprekinamas ir kitaip. Jau minètas „,vaizdas pro langą“ "žvelgiant ne tik iš senamiesčio perspektyvos, bet ir iš naujų, dažniausiai aukštuminių pastatų i jij, iggauna apčiuopiamą rinkos vertę, ir tai lemia, kad itin užkeliamos nekilnojamojo turto kainos. Ṣ̌̇ reiškinị galima būtų laikyti akivaizdžiu parazitavimo išnaudojant paveldą atveju.

Neabejotina, kad miesto įvaizdis kaip prekè užsienio rinkoje pritraukiant turistų srautus ir investicijas atlieka didžiuli vaidmeni, tačiau „vidinis“ ir „išorinis“ to paties miesto suprekinimas gali anaiptol nesutapti (pvz., žinome, kad Ryga ar Vilnius britams yra patrauklūs ne dèl savojo paveldo, bet kaip pigių ir kokybiškų bernvakarių vieta). Kita vertus, panašiai atsitinka ir su literatūrinių vietovių lankymu. Tokie miestai - tai tarsi rašytojo, jo kūrinių, realių vietų, kur jis gyveno, ir knygose aprašytų simbiozė. Turistai trokšta pasivaikščioti būtent ulisiškojo Dublino gatvèmis, išgerti alaus būtent šveikiškoje Prahoje, aplankyti būtent šekspyriškąji Stratfordą prie Eivono, pamukiškąji Stambulą (10 pav.) arba dostojevskiškąji Sankt Peterburgą ir patys pasijusti žinomų autorių knygų personažais.

Analogišku literatūriniam galima laikyti ir kinematografinị (garsių filmų inscenizacijų vietos, pvz., „Šindlerio sąrašo “ Varšuva, „Lūšnynų milijonieriaus“" Mumbajus ir t. t.) bei muzikinį turizmą - žymių kompozitorių (Europos kultūros kelių instituto inicijuotas „Mocarto kelias“, sujungęs 5 Europos miestus, kuriuose jis yra gyvenęs ar koncertavęs), atlikejjų (Elvio Preslio realūs ir virtualūs muziejai) ir t. t. atminties vietas. Šiam tipui iš dalies priskirtinas ir „siaubo turizmas", pavyzdžiui, Londone egzistuoja maršrutas „Džeko Skerdiko pèdsakais“.

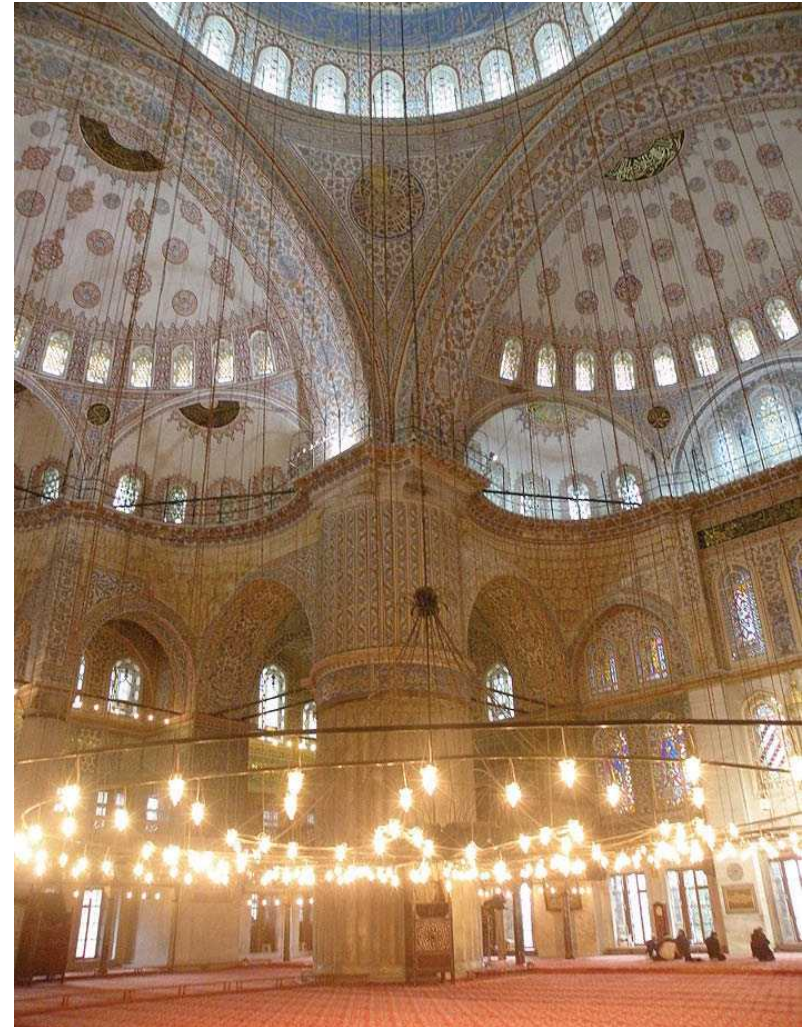

10 pav. Turistus ypač traukia ikoniniai miestu simboliai. Stambulo Mèlynoji mečetė, Turkija. Ž. Mikailienès nuotr.

Fig. 10. Iconic symbols of cities especially attract tourists. The Blue Mosque in Istanbul, Turkey. Photo by Ž. Mikailienè

Nors urbanistinè paveldosauga yra iki šiol glaudžiai susijusi su vietos kolektyvinio (nacionalinio, regioninio ar lokalaus) tapatumo legitimacija ir stiprinimu, bet lygiai taip pat šiandien aktualus tampa ir miesto pristatymas bei pateikimas tarptautinei turizmo paslaugų rinkai. Abu šie, atrodytų, priešingi veiksniai gali sukelti panašų efektą - jau minètą urbanistinių formų standartizaciją ir vadinamąji saugomų vietų „kataloginị supaveldinimą“, kuris ypač ryškus lokaliame lygmenyje (pvz., Vilniaus Gedimino prospekto rekonstrukcija), kai žibintai, šiukšliaděžès, gatvès, šaligatvio dangos ir t. t. parenkamos taip, kad atrodytų tarsi istoriškos, o nauji pastatai aprengiami neo-vernacular - historicist stiliumi. Šis paradoksalus reiškinys anksčiausiai buvo pastebetas XX a. 7-8 dešimtmečiais tokiuose Europos miestuose kaip Norvičas, Kolmaras, Deventris bei Bremenas. Tokiu būdu unikalios istorinès vietovès tapo standartizuotomis ir mažai viena nuo kitos besiskiriančiomis, nors ir lengvai atpažistamomis kaip istorinès (Ashworth 1998).

Kitas logiškas šios tendencijos tęsinys būtų istorinès stilizacijos, pavyzdžiui, Vilniaus Tymo kvartalo pseudoistorinių pastatų grupe (11 pav.) ir vadinamieji postmodernieji pastišai, kai greta autentiškų istorinių 
pastatų ir struktūrų arba net ant jų (sic!) statomi ultrašiuolaikiniai statiniai iš stiklo ir betono (Klaipedos Žvejų g. pastatai, stiklinis antstatas ant pastato Kauno Laisvès alejoje ir t. t.). Visa tai galiausiai veda prie vadinamojo „postmoderniojo antikvarizmo“, kai ištisos urbanistinès struktūros sukuriamos imituojant istorinius miestų ar architektūrinių objektų ịvaizdžius. Bene žinomiausias tokio simuliakrinio miesto pavyzdys - Las Vegas JAV, įsikūręs dykumoje ir dèl kazino verslo išaugęs iki ispūdingu matmenų teminio parko, kuriame ciniškai išnaudojami Europos ir pasaulio urbanistinio paveldo šedevrų ịvaizdžiai. Taip miestai ir jų ženklai „išvietinami“, o „postmodernusis antikvarizmas“ sugeba ištrinti pasaulio geografines bei chronologines ribas.

Analogiškas tematizavimas, beje, itin mejgiamas ir Lietuvos didžiųjų prekybos ir pramogų centrų architektų bei dizainerių. Juose įsikūrusių kavinių interjerai mègdžioja antikinę, gotikinę, renesansinę ar tiesiog abstrakčią retro stilistiką, jau nekalbant apie iki šiol lankytojų stoka nesiskundžiančių kaimiško tipo užeigu apipavidalinimą. Liaudiško stiliaus kavinių bumas, priskirtinas „naujojo kaimietiškumo“ (new ruralism (Cuthbert 2006: 122-126)) apraiškoms, rodytų ir pirmuosius perversiškus paveldo industrijos Lietuvoje požymius. Turimas omenyje heterogeniškų, tradicinei kaimo kultūrai svetimų elementų atsiradimas ją imituojančioje miesto erdveje (kontrastas tarp tokių i̇staigų eksterjero ir bendro šiuolaikinès architektūros pastato vaizdo, televizorių ekranai, picos valgiaraštyje, trumpi padavejuc sijonukai ir pan.). Visa tai kavinių lankytojui siunčia istoriškai klaidinančią informaciją, jau nekalbant apie „kaimiškumo“

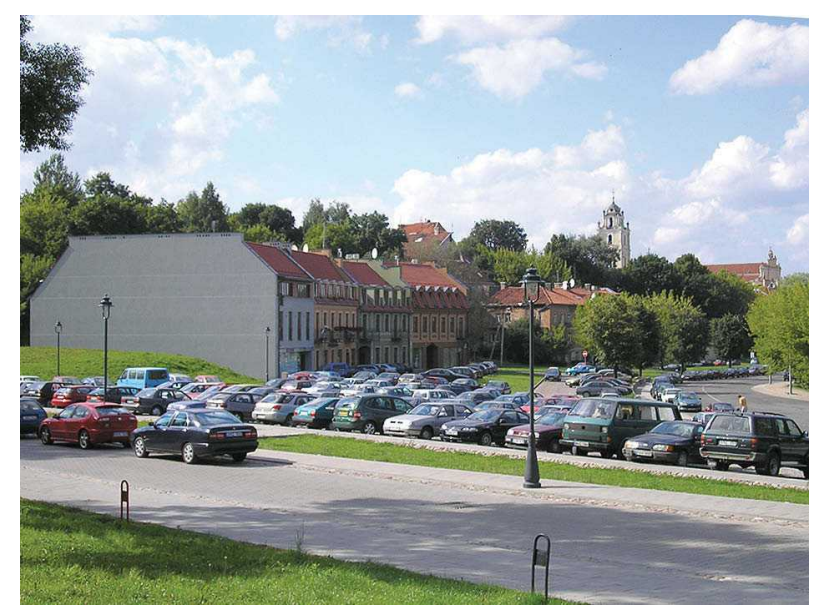

11 pav. Istorinès stilizacijos dažnai klaidina žiūrovą savo menamu autentiškumu. Vilniaus Tymo kvartalo fragmentas. R. Čepaitienès nuotr.

Fig. 11. Historical stylizations frequently mislead spectators by their pretend "authenticity". The Tymas Quarter fragment in Vilnius. Photo by R. Čepaitienè ir „etnografiškumo“ perviršį interjeruose, kai atvirai demonstruojamas etnokičas.

Kita vertus, klaustina, ką bendro su jų prototipais beturi akropoliai ir babilonai, eifeliai, bruklinai ir tilžés - šiuolaikinès prekybinès alèjos, pasivadinusios metaforinèmis aliuzijomis i i praeities miestus ar jų simbolius? Kaip mateme, ne tik kuriami tariami miestai (Misik 2008), bet ir autentiškas istorinio miesto audinys yra vienais ar kitais tikslais fiziškai ar simboliškai perdirbamas tam, kad tenkintu mūsu ịsivaizdavimo, koks turi būti senasis miestas, ir jo vartojimo poreikị, nepaisant šiomis dingstimis naikinamo jo materijos, formos, funkcijos bei apsupties (12 pav.) autentiškumo. Nors paveldosaugoje senųjų pastatų išorei bei interjerui taikomi tam tikri griežti autentiškumo išlaikymo reikalavimai, ribojantys jų perstatymo bei modernių technologijų (liftai, kondicionavimo sistemos, komunikacijos, apšvietimas ir pan.) įdiegimo galimybes (Ashworth, Tunbridge 2000: 109), tačiau bent jau Vidurio ir Rytų Europoje bei Lietuvoje šios sąlygos verslininkų dažnai tiesiog ignoruojamos: stiklu uždengiamos vidinès kiemų erdvès, taip gaunamas papildomas komercinis plotas, pastatai paaukštinami, iškertamos naujos angos, patalpos perplanuojamos, parterineje dalyje drastiškai platinamos vitrinos ir t. t. (Gražulis 2010). Savo ruožtu privatizuotos buvusios viešosios erdvès (rakinami kiemai) tampa nebeprieinamos kitiems miestiečiams bei miestų svečiams.

Taigi, ką šie liūdnoki baigiamieji pastebejjimai sako apie šiuolaikinių visuomenių požiūrị ị praeitị apskritai? Neoliberaliosios ideologijos nuolat reprodukuojamame amžiname „dabar“ ji tampa tik estetiškai patraukliomis

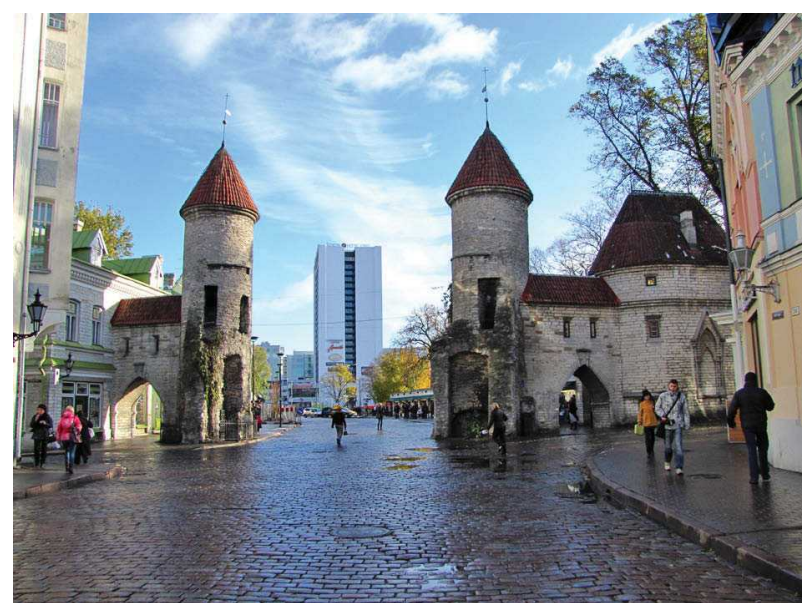

12 pav. Skirtingų epochų ir stilių priešpriešinimas lemia keistus kontrastus. Vieneri iš Talino gynybinès sienos vartų. V. Kubiliaus nuotr.

Fig. 12. Contraposition of the different epochs and styles frequently generate bizarre contrasts. The gates of the defence wall in Tallinn. Photo by V. Kubilius 
ir komerciškai paklausiomis nuorodomis į neapibrèžtą „aukso amžių“, nesvarbu, ar jis būtų siejamas su „gimtojo sodžiaus"idile ar su Europos aukštosios kultūros šedevrais. Taip paveldo vertybès lengvai pasiduoda „padaromumo" ir perinterpretavimo logikai, o istorinių, turistinių miestų suprekinimas tampa ryškiausiu praeities eksperimentinès sklaidos lauku.

\section{Išvados}

1. Kaip matėme, istorinių miestų apsauga bei naudojimas šiandien kyla iš daugelio, kartais viena kitai prieštaraujančių, paskatų: lokalių, nacionalinių, regioninių, globaliųjų. Todèl šiuolaikinèje miestų panaudoje persipina skirtingi ir nevienareikšmiškai traktuotini motyvai - jų suprekinimas „,vidaus reikmèms" (žemės fondo ir nekilnojamojo turto kainų augimas, tariamai viešų, vartojimą skatinančių erdvių reprodukavimas ir t. t.) ir "išorès reikmèms“ (miestų tarptautinio konkurencingumo pritraukiant investicijas skatinimas, jų ịvaizdžių kūrimas turizmo rinkai, paveldo industrijos produktų bei paslaugų sektoriaus ir infrastruktūros pletra ir t. t.). Anksčiau išvardintos aplinkybès rodo, kad laisvosios rinkos ekonomika bei nepaliaujamai intensyvejantys informacijos srautai kelia naujus ekonominius, socialinius bei politinius iššūkius miestams, verčiamiems sparčiai prisitaikyti prie nuolat kintančių sąlygų bei siekti, kad atitiktų tarptautines tendencijas bei reikalavimus ir tuo pat metu bandyti pasiūlyti ir tinkamas gyvenimo sąlygas tiek miestiečiams, tiek miesto svečiams.

2. Istoriniai, turistiniai miestai šiandien neišvengiamai susiduria su tarptautinès paveldo industrijos daromu poveikiu. Postmoderniajai vietos patirčiai būdingas stilių ir objektų eklektizmas, siūlomų paslaugu standartizacija bei niveliacija, pasiekiama naudojant „makdisnejizacijos“ ir tematizavimo efektus. Dažnai toks sterilizuotas, stereotipizuotas bei komercializuotas urbanistinio paveldo perteikimas sukuria vienalaiki, iš konteksto išplèštą miesto praeities vaizdą, taip paneigdamas istorini procesualumą. Tad tai gali prisideti ne prie vietos tapatumo (place identity) išlaikymo, o, atvirkščiai, prie jo griovimo.

3. Šiandien $\mathfrak{i}$ istorinị miestą dažnai žiūrima kaip ị nostalgiško bėgimo nuo dabarties sunkumų ir neužtikrintos ateities vietą, kurioje esama komfortiškesnès ir „saugesnès“ patirties. Taip manipuliacijos su istoriškumu mieste tampa negebejjimo valdyti dabartị ir numatyti ateiț išraiška. Akivaizdu, jog istorinių miestų lankytojai - turistai - neieško moksliškai pagrịstos informacijos. Juos gali tik iš dalies dominti pati istorinè miesto tikrovè. Atvykèliai siekia ịgyti naują, išskirtinę patirtị, prisiliesti prie kitokios realybès, pagrịstos apčiuopiamomis, materialiomis praeities liekanomis, jiems tai yra per paveldą ar jo įvaizdžius patiriamo, kad ir dirbtinai sukonstruoto, „kitoniškumo“ esmè.

4. Tačiau ị istorinių miestų ateitị galima žiūrèti ir ne tik pesimistiškai. Dèl paveldo industrijos tebesiplečianti urbanistinio paveldo apimtis ir ịvairejančios sąveikavimo su juo galimybės skatina žymiai platesniu mastu ir kokybiškiau domètis praeitimi, o autentiškos kultūros vertybès nūnai regimos ir kaip atsvara globalizacijos veikiamai gyvenamosios aplinkos kaitai. Galiausiai miestai jų gyventojams bei lankytojams atveria ne tik savo praeities klodus, bet ir tampa ịvairialypés dabarties kultūrų komunikacijos erdve.

\section{Literatūra}

Abensour, M. 1997. De la composité. Architectures et régimes totalitaires. Paris: Sens and Tonka.

Ashworth, G. J. 1994. From History to Heritage - from Heritage to Identity in Search of Concepts and Models, in Ashworth, G. J. and Larhkam, P. J. (Ed.). Building a New Heritage. Tourism, Culture and Identity in the New Europe. London: Routledge, 13-30.

Ashworth, G. J. 1995. Heritage, Tourism and Europe: a European Future for European Past?, in Herbert, D. T. (Ed.). Heritage, Tourism and Society. London: Mansell, 68-84.

Ashworth, G. J. 1998. The Conserved European City as Cultural Symbol: the Meaning of the Text, in Graham, B. (Ed.). Modern Europe. Place, Culture and Identity. London: Arnold, 261-286.

Ashworth, G. J. 2009. Kaip turistai veikia paveldo vietas?, iš Kultūros paveldas ir turizmas. Vilnius: Versus aureus. $54 \mathrm{p}$.

Ashworth, G. J.; Tunbridge, J. E. 2000. The Tourist-Historic City. Retrospect and Prospect of Managing the Heritage City. Oxford: Elsevier Science Ltd.

Ashworth, G. J.; Tunbridge, J. E. 2003. Whose Tourist-Historic City? Localising the Global and Globalising the Local, in Globalisation and Contestation. London: Routledge, 12-34.

Bianchini, F. 1999. Cultural Planing for Urban Sustainability, in Nystrom, L. (Ed.). City and Culture: Cultural Processes and Urban Sustainability. Kalmar: The Swedish Urban Environment Council, 34-51.

Castells, M. European Cities, the Informational Society and the global Economy [interaktyvus], [žiūrèta $2009 \mathrm{~m}$. sausio 22 d.]. Prieiga per internetą: <http://www.acturban.org/ biennial/doc_planners/castells_european_informational_society_global_economy.htm >.

Craik, J. 1997. The Culture of Tourism, in Rojek, C. and Urry, J. (Ed.). Touring cultures: Transformations of Travel and Theory. London: Routledge, 113-136.

Cuthbert, A. R. 2006. The Form of Cities. Political Economy and Urban Design. Oxford: Blackwell Publishing. 
Čepaitienè, R. 2008. Daugiakultūris miestų paveldas: interpretacijos problemos ir perspektyvos, Lietuvos istorijos studijos (21): 86-101.

Čepaitienè, R. 2009. Interpretuojant daugiakultūrị Vilnių: kontekstai, problemos ir galimybès, in Naujasis Vilniaus perskaitymas: didieji Lietuvos istoriniai pasakojimai ir daugiakultūris miesto paveldas. Vilnius, VU, 49-78.

Dogshon, R. A. 1999. Human Geografy at the End of Time? Some Thoughts on the Notion of Time-Space Compression, Environment and Planning D: Society and Space 17(5): 607-620. doi:10.1068/d170607

Benyon, J.; Dunketley, D. (Ed.). 2001. Globalisation: The Reader. London: Routledge.

Fulcher, J. 2007. Kapitalizmas. Labai trumpas įvadas. Vilnius: Eugrimas.

Graham, B. (Ed.). 1998. The Past in Europe's Present: Diversity, Identity and the Construction of Place, in Modern Europe. Place, Culture, Identity. London: Arnold, 19-49.

Gražulis, A. 2010. Vilniaus senamiesčio žaizdos (pastarųjų 15 metų pokyčiai ir tendencijos), Kultūros barai, Nr. 3-4.

Harvey, D. 1989. The Condition of Post-Modernity. Oxford: Basil Blackwell.

Herbert, D. T. (Ed.). 1995. Heritage Places, Leisure and Tourism, in Heritage, Tourism and Society. London: Mansell, 2-18.

Hewison, R. 1987. The Heritage Industry. Britain in a Climate of Decline. London: Methuen Paperback.

Jokinen, E.; Veijola, S. 2002. The Disoriented Tourist. The Figuration of the Tourist in Contemporary Cultural Critique, in Rojek, C. and Urry, J. (Ed.). Touring Cultures. Transformations of Travel and Theory. London: Routeldge, 23-51.

Kirshenblatt-Gimblett, B. 1998. Destination Culture: Tourism, Museums and Heritage. Berkeley: University of California Press, 150-151.

Latouche, S. 1996. The Westernization of the World. Cambridge: Polity Press.

McLeod, N. 2006. Cultural Tourism: Aspects of Authenticity and Commodification, in Smith, M. K. and Robinson, M. (Ed.). Cultural Tourism in a Changing World. Politics, Participation and (Re)Presentation. Cannel View Publications, 182-188.

Misik, R. 2008. Simuliuojami miestai, solidus gyvenimas. Prekybos alejos kaip paradigminis kapitalizmo gyvenimo stilius, Kultūros barai (1): 59-63.

Muzyn, M. A. 2009. Kaip turizmas veikia urbanistinị paveldą: naujos galimybès ir keliamos grèsmès. Krokuvos pavyzdys, Kultūros paveldas ir turizmas. Galimybès, poveikis, partnerystè ir valdymas. Vilnius: Versus aureus, 61-66.

Orbaşli, A. 2002. Turists in Historic Towns. Urban Conservation and Heritage Management. London: Taylor $\&$ Francis e-Library.

Pine, J. B; Gilmore, J. H. 1999. The Experience Economy: Work is Theatre \& every Business a Stage. Harvard Business School Press.

Ritzer, G.; Liska, A. 2002. McDisneyization and "Post-Tourism", in Rojek, C. and Urry, J. (Ed.). Touring Cultures. Transformations of Travel and Theory. London: Routledge, 96-109.

Robertson, R.; White, K. E. 2003. Globalization - Critical Concepts in Sociology. London: Routledge.
Rypkema, D. D. 2005. Celebrating our Urban Heritage. Globalisation, Urban Heritage, and the 21st Century Economy, in Global Urban Development 1(1) May [interaktyvus] [žiūrèta $2007 \mathrm{~m}$. lapkričio $21 \mathrm{~d}$.]. Prieiga per internetą: <http://www.globalurban.org/Issue1PIMag05/ Rypkema\%20PDF.pdf $>$.

Sullivan, S. 2007. Cultural Values and Cultural Imperialism, in Smith, L. (Ed.). Cultural Heritage. Critical Concepts in Media and Cultural Studies. London: Routledge 2: $160-171$.

Urry, J. 1990. The Tourist Gaze. London: Sage Publications.

Urry, J. 1995. Consuming Places. London: Routledge.

Vaitkuvienè, A. 2006. Paveldo industrija Lietuvoje, Lietuvos istorijos studijos 17: 87-96.

Wagner, P. 2000. From Monuments to Human Rights: Redefining "Heritage" in the Work of Council of Europe, in Forward Planning: the Functions of cultural Heritage in the changing Europe. Expert's contibutions [interaktyvus], 9-28 [žiūrèta 2009 vasario 11 d.]. Prieiga per internetą: <http://www.coe.int/T/E/Cultural_Co-operation/ Heritage/Resources/ECC-PAT(2001)161.pdf $>$.

Žukauskaitè, A. 2004. Geismo mašinos: psichoanalitinè ir šizoanalitiné perspektyvos, Filosofija, sociologija (3): 27-32.

\section{THE COMMODIFICATION OF THE PAST IN AN URBAN SPACE}

\section{R. Čepaitienè}

Abstract. The article deals with several problematical units concerned with commercialization of the past in the postindustrial, postmodern consumer societies. Primarily, the process of the commercialization of urban centres - especially old historical cities and their images - is analysed in the context of contemporary global culture economics; also, questions regarding forms and shapes this process assumes are raised. Secondly, the consideration regarding the meaning of this process is given, in other words, what is it telling about the condition of our society and attitudes towards the past? Undoubtedly, an adequate assessment of the knowledge of socio-economic tendencies, which have to cope with cities influenced by neoliberalism, is very important and relevant to post-colonial and post-communist countries, which, like Lithuania, are still seeking for their identity in the face of economical and cultural globalization challenges.

Keywords: historical cities, postindustrial society, neoliberalism, commodification, consumerism, heritage industry, cultural tourism.

\section{RASA ČEPAITIENE}

Dr, research worker, Lithuanian Institute of History, Department of the XXth Century History, Kražiu g. 5, 01108 Vilnius, Lithuania.E-mail.rasa.cepaitiene@if.vu.lt

Publications: author of 4 monographs and about 50 research papers. Research interests: cultural heritage and collective memory studies, Soviet culture and post-soviet transformation. 